CLIN. EXPI. METASTASIS, 1986, vol. 4, NO. 1, 51-61

\title{
Phorbol ester binding and phorol ester-induced arachidonic acid metabolism in a highly responsive murine fibrosarcoma cell line and in a less-responsive variant
}

\author{
ALEXANDER C. BATCHEV, BRUCE L. RISER, \\ ERIN G. HELLNER, SUZANNE E. G. FLIGIEL \\ and JAMES VARANI \\ Department of Pathology, University of Michigan Medical School, \\ Ann Arbor, Michigan 48109, U.S.A.
}

(Received 13 October 1985; accepted 26 December 1985)

\begin{abstract}
Phorbol ester binding was examined in two lines of murine fibrosarcoma cells. The two cell lines were isolated from the same parent tumor but respond differentially to stimulation with phorbol esters. In one of the lines, these agents stimulate a rapid attachment and spreading response and induce directional migration. The other cell line does not migrate in response to stimulation with phorbol esters and the attachment and spreading response is slow. The cell line which responds actively to phorbol ester stimulation is highly malignant when injected into syngeneic animals while the other line is of low tumorigenicity and is virtually non-metastatic. In spite of these differences, both lines were found in the present study to bind $\left[{ }^{3} \mathrm{H}\right] 4 \beta$-phorbol-12 $\beta, 13 \alpha$-dibutyrate in a receptormediated fashion. The characteristics of binding were virtually identical between the two cell lines. In additional studies, arachidonic acid metabolism was examined in the same two lines. In the highly responsive line, PMA stimulated a rapid release of $\left[{ }^{3} \mathrm{H}\right]$ arachidonic acid and its conversion into cyclooxygenase and lipoxygenase products. In the less-responsive line, PMA stimulated a slower release of $\left[{ }^{3} \mathrm{H}\right]$ arachidonic acid from prelabeled cells. The quantity of arachidonic acid metabolites produced was also much less. These studies suggest that the disparity between the two cell lines in their response to phorbol ester stimulation is not the result of differences in the initial interaction between the cells and ligand but may result from alterations in their signal transductance mechanism. This may be the result of inherent differences in capacity for arachidonic acid metabolism.
\end{abstract}

\section{Introduction}

Many different types of malignant tumor cells are capable of chemotactic responses [23] and there is evidence to suggest that chemotactic responses may play a role in the invasion and metastatic processes $[13,16]$. The cellular and molecular basis of the chemotactic response in tumor cells has not been fully delineated but some of the key features are beginning to be understood. Factors which produce a stimulation of motility also induce an increase in cell-to-substrate adhesiveness $[24,25]$. These biological events are presumed to result from the binding of the stimulating ligand to specific cellular receptors, although with most tumor cells, binding studies have not been carried out. One exception to this is the Walker 256 carcinosarcoma line. These cells have been shown to bind the chemotactically active phorbol esters and chemotactically active $N$-formyl peptides in a receptor-mediated manner $[6,14,17]$. With regards to phorbol ester binding, the Walker cells appear to be similar to a number of other nonmalignant cell types which have been 
characterized $[5,7,11,18,19,21]$. They also appear to be similar to leukocytes with regards to $N$-formyl peptide binding (in terms of affinity and specificity) but have many fewer receptors than rabbit or human polymorphonuclear granulocytes $[1,28]$.

The present study was undertaken as part of our effort to delineate the biological basis of stimulus-coupled responses in malignant cells. In this study we compared two lines of murine fibrosarcoma cells (derived from the same parent tumor) for responsiveness to stimulation with phorbol esters. In one of the lines, stimulation led to a rapid cell-to-substrate attachment and spreading of the cells. Stimulation of these cells also resulted in enhanced motility. The other cell line did not demonstrate increased motility and cell attachment and spreading was much slower. In spite of these differences in biological responsiveness, the binding of phorbol esters by the two cell lines was virtually identical. In further studies it was shown that arachidonic acid was released from both lines in response to phorbol ester stimulation and metabolized into cyclooxygenase and lipoxygenase metabolites. However, the more highly responsive cells released arachidonic acid more rapidly and produced greater quantities of arachidonic acid metabolites than the less-responsive cells. These findings suggest that the disparity in biological activity between the two lines is not the result of differences in the initial interaction of the cells with the active ligand. There may be differences, however, in the signal transduction mechanism between the cells and this may be related to differences in the inherent capacity of the cells for arachidonic acid metabolism.

\section{Materials and methods}

Cells

Two murine fibrosarcoma cell lines, designated as 1.2 and $1.2 /$ anti- $\mathrm{B}^{\mathrm{r}}$ respectively, were used in this study. The two lines were established in our laboratory from a 3-methylcholanthrene-induced tumor in a $\mathrm{C} 57 \mathrm{BL} / 6$ mouse. The isolation and characterization of these lines have been described in our previous report [27]. The 1.2 cell line is highly malignant when injected into syngeneic mice. The $1.2 /$ anti- $B^{r}$ cell line is a low-malignant variant. For the present study, both lines were maintained in monolayer culture using RPMI-1640 medium supplemented with 10 per cent fetal bovine serum, $100 \mathrm{U} / \mathrm{ml}$ of penicillin, $100 \mu \mathrm{g} / \mathrm{ml}$ of streptomycin and $2.5 \mu \mathrm{g} / \mathrm{ml}$ of fungizone as the culture medium. The cells were grown at $37^{\circ} \mathrm{C}$ in $5 \mathrm{per}$ cent $\mathrm{CO}_{2}$ and subcultured by trypsinization as required. Prior to use, both cell lines were shown to be free of mycoplasma contamination.

\section{Reagents}

Unlabeled phorbol and phorbol esters were obtained from Sigma Chemical Company (St Louis, Missouri). These included $4 \beta$-phorbol (phorbol), $4 \beta$-phorbol12-myristate-13-acetate (PMA), 4 $\beta$-phorbol-12 $\beta, 13 \alpha$-dibutyrate (PDB), $4 \beta$ phorbol-12, 13-dibenzoate (PDBz) and $4 \beta$-phorbol-12, 13-diacetate (PDA). Upon arrival in the laboratory, each of the agents was resuspended in dimethyl sulfoxide at $1 \mathrm{mg} / \mathrm{ml}$, aliquoted into small vials and frozen at $-20^{\circ} \mathrm{C}$. Tritiated PDB $\left.\left({ }^{3} \mathrm{H}\right] \mathrm{PDB}\right)$ was obtained from New England Nuclear (Boston, Massachusetts). The stock solution contained $12 \cdot 2 \mathrm{Ci} / \mathrm{mmol}$ in ethanol. 


\section{Cell spreading on plastic culture dishes}

Spreading of the cells on $35 \mathrm{~mm}$ (diameter) plastic culture dishes was used as the indicator of biological activity. Although the phorbol esters induce cell-to-substrate attachment and motility [26] in addition to cell spreading, spreading proved to be the most convenient parameter to quantify, particularly when a large number of samples were to be analyzed at a single time point. Each dish received $1.9 \mathrm{ml}$ of RPMI-1640 culture medium containing 10 per cent fetal calf serum and the appropriate amount of the various phorbol analogues. The cells $\left(5 \cdot 0 \times 10^{5}\right.$ per dish) were then added and the dishes incubated at $37^{\circ} \mathrm{C}$. At various times later, the non-adherent cells were removed from control and treated dishes and counted with an electronic particle counter. The dishes were flooded with 2 per cent glutaraldehyde and the number of spread cells was determined using a microscope with a calibrated grid in the eyepiece.

\section{Binding assay}

The ligand binding assays were carried out using the protocol described previously with the Walker 256 carcinosarcoma cells [6]. This is a modification of the procedure described by Sando et al. for peripheral blood lymphocytes [19]. The cells were suspended in RPMI-1640 medium supplemented with 10 per cent fetal bovine serum at $12 \times 10^{6}$ cells per $\mathrm{ml}$ and $0.4 \mathrm{ml}$ of cell suspension was aliquoted into $12 \times 75 \mathrm{~mm}$ glass tubes. Following this, $0 \cdot 1 \mathrm{ml}$ of culture medium, with the desired amount of $\left[{ }^{3} \mathrm{H}\right] \mathrm{PDB}$ and (in some cases) various amounts of non-radioactive phorbol or phorbol esters, were added to the tubes. The tubes were then incubated at $37^{\circ} \mathrm{C}$ and 5 per cent $\mathrm{CO}_{2}$. At the end of the incubation period (ranging from 2 to $120 \mathrm{~min}$ ), the cells were collected on Whatman filters and separated from the unbound radioactivity in a Millipore filtration manifold (Millipore Co., Bedford, Massachusetts). Fifty millilitres of phosphate-buffered saline at room temperature was used to wash the cells from the reaction tubes onto the collection filters. The filters containing the cells with the bound $\left[{ }^{3} \mathrm{H}\right] \mathrm{PDB}$ were counted in glass vials containing aqueous scintillation fluid for $10 \mathrm{~min}$. The counting efficiency for the $\left[{ }^{3} \mathrm{H}\right] \mathrm{PDB}$ was 32 per cent. Non-specific binding of $\left[{ }^{3} \mathrm{H}\right] \mathrm{PDB}$ to the cells was estimated from the binding in the presence of $3 \mu \mathrm{M}$ unlabeled PMA. Background counts were determined from incubations containing all of the reactants except the cells. Preliminary studies indicated that ligand binding was linear with cell number at the concentration of cells used. Binding data was analyzed by the Scatchard method [20] using the computer program, LIGAND [15].

\section{Arachidonic acid metabolism}

$\left[{ }^{3} \mathrm{H}\right]$ Arachidonic acid $(87 \mathrm{Ci} / \mathrm{mmol})$, obtained from New England Nuclear, was used to measure arachidonic acid release from the control and stimulated cells. Freshly harvested cells were labeled by preincubation for $2 \mathrm{~h}$ with $1 \mu \mathrm{Ci}$ $\left[{ }^{3} \mathrm{H}\right]$ arachidonic acid per $5 \times 10^{7}$ cells in $5 \mathrm{ml}$ RPMI-1640 culture medium supplemented with 10 per cent fetal bovine serum. Incubation was carried out at $37^{\circ} \mathrm{C}$ and 5 per cent $\mathrm{CO}_{2}$. During the labeling procedure, the cells were kept in tubes and maintained in suspension by gentle shaking. The distribution of the radioactivity within the labeled cells was determined by subjecting the labeled cells to a Folch extraction [9] and analyzing the chloroform-soluble fraction by thin-layer chromatography using a modification of the solvent system described by Skipski et al. [22]. 
Depending on the experiment, we were able to obtain $1-2 \times 10^{5}$ counts per minute $(\mathrm{CPM})$ of $\left[{ }^{3} \mathrm{H}\right]$ arachidonic acid incorporated per $1 \times 10^{6}$ cells. Nearly all of the incorporated material was found in the chloroform-soluble phase and when this material was analyzed, the radioactivity was found in bands co-migrating with phosphatidylcholine, phosphatidylinositol, phosphatidylserine and phosphatidylethanolamine. Less than 10 per cent of the chloroform-soluble radioactivity was in bands which co-migrated with free fatty acids, triglycerides and cholesterol esters. After labeling, the cells were centrifuged and washed twice in culture medium to remove unincorporated $\left[{ }^{3} \mathrm{H}\right]$ arachidonic acid. The cells were then put into tubes in aliquots, stimulated with PMA and incubated at $37^{\circ} \mathrm{C}$ and 5 per cent $\mathrm{CO}_{2}$. At various times thereafter, $200 \mu \mathrm{l}$ samples $\left(2 \times 10^{6}\right.$ cells) were removed from the tubes. The samples were added to $300 \mu \mathrm{l}$ phosphate-buffered saline and the cells separated from the supernatant fluid by centrifugation. Radioactivity in the supernatant fluid was then determined using a $\beta$-scintillation counter.

Levels of prostaglandin $\mathrm{E}_{2}\left(\mathrm{PGE}_{2}\right)$ and leukotriene $\mathrm{C}_{4}\left(\mathrm{LTC}_{4}\right)$ were quantified in control and stimulated cells. For these assays, the cells were harvested, washed four times in serum-free culture medium and incubated at $5 \times 10^{6}$ cells per $\mathrm{ml}$ of serumfree medium. At various subsequent times, the supernatant fluids (for $\mathrm{PGE}_{2}$ ) or the cells and supernatant fluid (for $\mathrm{TLC}_{4}$ ) were harvested, extracted and assayed. The extraction procedure involved precipitation of the protein with acetonitrile, and extraction of most neutral lipids from the acidified acetonitrile fraction with petroleum ether. After removal of the ether layer, the remaining aqueous phase was extracted twice with ethyl acetate and dried in air. The residue was redissolved in phosphate-buffered saline containing 0.1 per cent gelatin and assayed for the metabolites using radioimmunoassay (RIA) procedures. Assays for $\mathrm{PGE}_{2}$ were performed with antibodies and labeled ligand obtained from New England Nuclear. The limit of sensitivity was $3.8 \mathrm{pg}$ per tube. Cross reactivity of the antibody with related prostaglandins was low (less than 1.8 per cent). The $\mathrm{LTC}_{4}$ assay was also carried out using a New England Nuclear assay kit. The limit of sensitivity for this assay was $3.7 \mathrm{pg}$ per reaction tube. The antibody to $\mathrm{LTC}_{4}$ cross-reacted with $\mathrm{LTD}_{4}$ (55 per cent) and $\mathrm{LTE}_{4}(8 \cdot 6$ per cent) but showed low cross-reactivity (less than 1 per cent) with $\mathrm{LTB}_{4}$, mono-hydroxyeicosatetraenoic acids (mono-HETEs) and various prostaglandins. The actual assay procedures were carried out by the Ligand Core Laboratory at the Michigan Diabetes Research and Training Center (Ann Arbor, Michigan).

\section{Results}

\section{Biological response to phorbol esters}

Spreading of the cells on plastic culture dishes was used as an indicator of biological response to the phorbol esters. When PDB was used as the stimulating agent with the 1.2 cells, the cells rapidly attached to the plastic culture dishes and spread (figure 1). The effects were seen as early as $15 \mathrm{~min}$ after treatment and were dose responsive. Activity was observed at concentrations as low as $2 \mathrm{nM}$ and a halfmaximal response was achieved at approximately $25 \mathrm{nM}$. PDB also induced attachment and spreading in the $1.2 /$ anti- $B^{r}$ cells. With these cells, the response occurred much more slowly than with the 1.2 cells. Significant cell spreading was not observed until $1 \mathrm{~h}$ after treatment and the maximum difference between the treated and control cells was not seen until much later $(2 \mathrm{~h}$ or longer). 


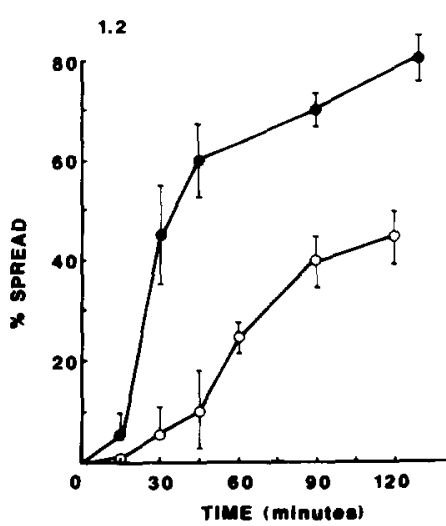

(a)

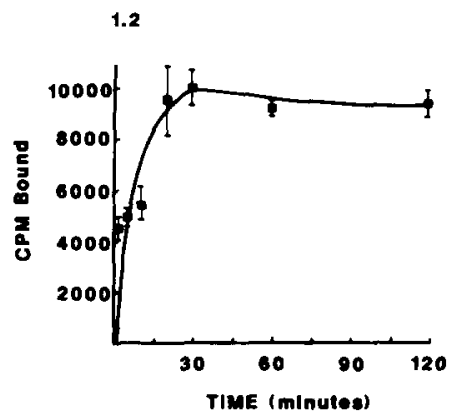

(c)

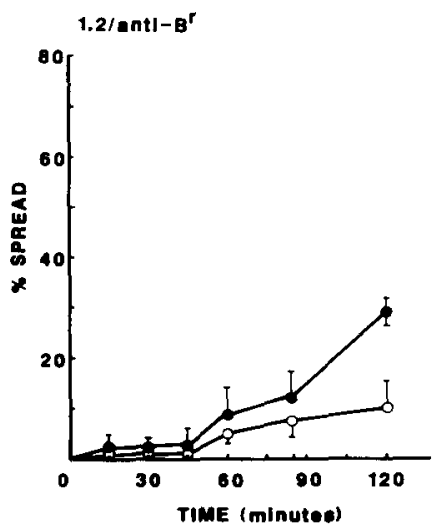

(b)

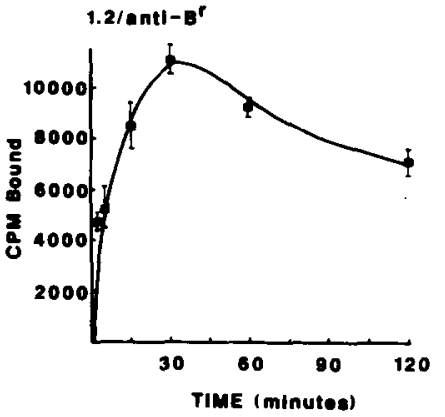

(d)

Figure 1. Time-course of PDB-induced spreading $(a, b)$ and $\left[{ }^{3} \mathrm{H}\right] \mathrm{PDB}$ binding $(c, d)$ by the 1.2 and $1.2 /$ anti-B $\mathrm{B}^{\mathrm{r}}$ cells. The spreading response is shown in the upper panels: $(a) 1.2$ cells and $(b) 1.2 /$ anti- $\mathrm{B}^{\mathrm{r}}$ cells. The spreading assay was carried out as described in the Methods section. Each value is the average of duplicate samples \pm the difference between the individual numbers and the averages in a single experiment. The experiment was carried out three times with very similar results $(O$, control; $\bullet, 80 \mathrm{nM}$ PDB). The time-course at $\left[{ }^{3} \mathrm{H}\right] \mathrm{PDB}$ is shown in the lower panels; $(c) 1.2$ cells and $(d)$ $1.2 /$ anti- $\mathrm{B}^{\mathrm{r}}$ cells. The binding assay was carried out as described in the Materials and methods section. Each value is the average of duplicate samples \pm the difference between the individual numbers and the averages in a single experiment. The experiment was carried out three times with very similar results.

Other phorbol esters, in addition to PDB, also stimulated cell spreading of the 1.2 and 1.2/anti-Br cells. These include PMA, PDBz and PDA. With each, the effects were dose responsive. PMA was the most active ligand, stimulating a half-maximal response in both cells at 5-10 nM. $\mathrm{PDBz}$ was intermediate (25-35 nM for halfmaximal response) and PDA was the least active (750-900 nM for half-maximal response). Interestingly, phorbol itself also showed activity at very high concentrations $(2 \mu \mathrm{M})$. We had seen no activity with this agent at concentrations up to $10 \mu \mathrm{M}$ in our previous study with the Walker 256 carcinosarcoma cells [6]. Kinetically, the response induced by the various PDB analogues were similar to the response induced by $\mathrm{PDB}$ itself (see figure 1). That is, the response of the 1.2 cells was very rapid while the $1.2 /$ anti- $\mathrm{B}^{\mathbf{r}}$ cells responded much more slowly. 


\section{$P D B$-binding studies}

Because of the kinetic differences between the 1.2 and $1.2 /$ anti- $\mathrm{B}^{\mathrm{r}}$ cells in their response to phorbol ester stimulation, we examined phorbol ester binding by the two lines. $\left[{ }^{3} \mathrm{H}\right] \mathrm{PDB}$ was used for this. The time-course of $\left[{ }^{3} \mathrm{H}\right] \mathrm{PDB}$ binding to the 1.2 and 1.2 /anti-B $\mathrm{B}^{\mathrm{r}}$ cells is shown in figure 1 . With both cell lines, binding was rapid. Peak binding was seen by $30 \mathrm{~min}$ and there was a fall-off at later time periods. The fall-off in the amount of bound $\left[{ }^{3} \mathrm{H}\right] \mathrm{PDB}$ at the later time-points is not unique to these cells. Similar findings have been made with other cell types $[6,7,19,21]$. The time-course of ligand binding is in accord with the kinetics of the biological response induced in the 1.2 cells. In the $1.2 /$ anti- $\mathrm{B}^{\mathrm{r}}$ cells, it appears that the delay in cell spreading is not due to slower ligand binding to these cells. Rather, the ligand bin is to these cells as rapidly as to the 1.2 cells.

The binding of $\left[{ }^{3} \mathrm{H}\right] \mathrm{PDB}$ by both cell lines was concentration dependent over the range of 9-270 $\mathrm{nM}$ and was saturable (not shown). At the highest concentrations used, over 90 per cent of the total binding was inhibited by excess ( $3 \mu \mathrm{M})$ PMA. When the binding data was plotted by the Scatchard method and analyzed using a single-site model, we estimated approximately $3 \cdot 8-4 \cdot 0 \times 10^{5}$ binding sites per cell for both cell types with $K_{d}$ in the range of $40-50 \mathrm{~nm}$. These values are in accord with the concentrations of PDB stimulating half-maximal biological responses with the 1.2 and 1.2/anti- $\mathrm{B}^{\mathrm{r}}$ cells.

Binding of the $\left[{ }^{3} \mathrm{H}\right] \mathrm{PDB}$ to both cell lines was also reversible. This was demonstrated by adding $3 \mu \mathrm{M}$ PMA to the cells $15 \mathrm{~min}$ after the cells had been incubated with $\left[{ }^{3} \mathrm{H}\right] \mathrm{PDB}$ and then incubating them for an additional $15 \mathrm{~min}$. The addition of the PMA 15 min after incubation with the $\left[{ }^{3} \mathrm{H}\right] \mathrm{PDB}$ released 91 per cent of the total radioactivity from the 1.2 cells and 84 per cent of the total radioactivity from the 1.2/anti- $\mathrm{B}^{\mathrm{r}}$ cells (not shown). Since it has already been demonstrated that non-specific binding accounts for approximately 10 per cent of the total binding, this indicates that nearly 100 per cent of the specific binding was reversible after $15 \mathrm{~min}$.

The analogues of PDB which induced cell spreading were also examined for ability to interfere with $\left[{ }^{3} \mathrm{H}\right] \mathrm{PDB}$ binding by the 1.2 and $1.2 /$ anti- $\mathrm{B}^{\mathrm{r}}$ cells. All three analogues (i.e. PMA, PDBz and PDA) competed with $\left[{ }^{3} \mathrm{H}\right] \mathrm{PDB}$. Inhibition was dose responsive with all of the analogues and there was a close relationship between those concentrations which induced a biological response and those concentrations which inhibited $\left[{ }^{3} \mathrm{H}\right]$ PDB binding (not shown).

\section{Arachidonic acid metabolism}

The 1.2 and $1.2 /$ anti- $B^{r}$ cells were prelabeled with $\left[{ }^{3} \mathrm{H}\right]$ arachidonic acid as described in the Methods section and incubated at $37^{\circ} \mathrm{C}$. At various times later, control cells and cells stimulated with PMA (16 nM) were examined for release of radioactivity into the culture fluid (figure 2). PMA stimulated a rapid release of radioactivity from the 1.2 cells. Increased release (over baseline values) was seen as early as $5 \mathrm{~min}$ after stimulation and peaked at $30 \mathrm{~min}$. At later times, the amount of radioactivity recovered from the culture fluids was decreased. With the $1.2 /$ anti- $B^{r}$ cells, significant differences between the control and PMA-stimulated cells were not observed at the earliest time points ( 5 and $15 \mathrm{~min}$ ), but were seen by $30 \mathrm{~min}$. In addition to these differences in the kinetics of release, differences in the total amount released were also observed. The total amount released was much greater from the 1.2 cells than from the 1.2 /anti-B $\mathbf{B}^{\mathbf{r}}$ cells (figure 2 ). It can also be seen from figure 2 that 


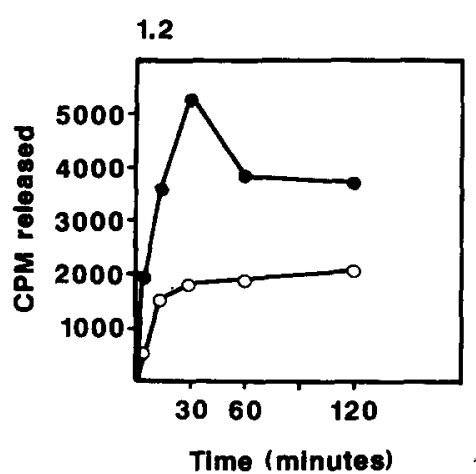

(a)

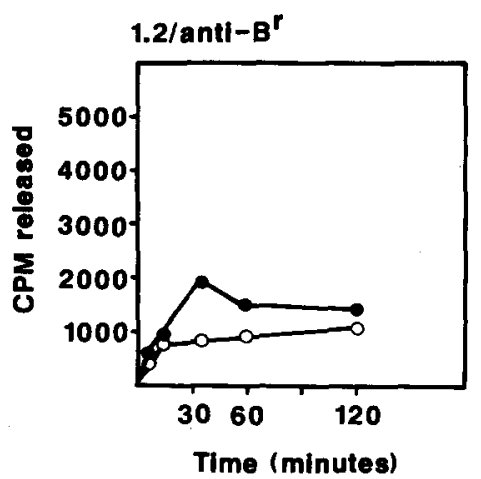

(b)

Figure 2. Release of radioactivity from $\left[{ }^{3} \mathrm{H}\right]$ arachidonic acid pre-labeled 1.2 cells $(a)$ and 1.2 /anti- $\mathrm{B}^{\mathrm{r}}$ cells $(b)$. The cells were pre-treated with $\left[{ }^{3} \mathrm{H}\right]$ arachidonic acid as described in the Methods section and then incubated in control medium or medium containing $16 \mathrm{nM}$ PMA. The values shown are the amount of radioactivity recovered from the culture fluid at various subsequent times. Values are averages of duplicate tubes in a single experiment where the duplicate values were always within 15 per cent of the averages. The experiment was carried out seven times with very similar results. O, Unstimulated; 9 , 16 nM PMA.

the spontaneous release of radioactivity from the 1.2 cells was greater than from the $1.2 /$ anti- $B^{r}$ cells. These results are similar to what we have previously reported [8].

The 1.2 and 1.2/anti- $B^{r}$ cells were also examined for the synthesis of specific arachidonic acid metabolites. For these experiments, the cells were compared at a single time point ( $4 \mathrm{~h}$ after stimulation). PMA stimulated the production of $\mathrm{PGE}_{2}$ in both cell lines and the ratios of the amounts produced in the stimulated versus control cells were very similar (the table). As was seen with the release of radioactivity, however, the amount of $\mathrm{PGE}_{2}$ produced in the 1.2 cells was much greater under both control and stimulated conditions than in the $1.2 /$ anti- $\mathrm{B}^{\mathrm{r}}$ cells. TPA also stimulated the production of $\mathrm{LTC}_{4}$ in the 1.2 cells but we detected no

\section{Production of $\mathrm{PGE}_{2}$ and $\mathrm{LTC}_{4}$ by control and PMA-stimulated 1.2 and 1.2/anti-B cells ${ }^{a}$.}

\begin{tabular}{lccc} 
& & \multicolumn{2}{c}{$\begin{array}{c}\text { Amount produced } \\
\left(\mathrm{ng} / 5 \times 10^{6} \text { cells } / 4 \mathrm{~h}\right)\end{array}$} \\
\cline { 3 - 4 } Cell line & Stimulation & $\mathrm{PGE}_{2}^{b}$ & $\mathrm{LTC}_{4}^{b}$ \\
\hline 1.2 & None & $10 \cdot 8 \pm 1 \cdot 1$ & $0 \cdot 2 \pm 0 \cdot 1$ \\
$1.2 /$ anti-B $^{\mathrm{r}}$ & $16 \mathrm{nM}$ PMA & $25 \cdot 3 \pm 3 \cdot 3$ & $1 \cdot 0 \pm 0 \cdot 1$ \\
& None & $1 \cdot 0 \pm 0 \cdot 2$ & $0 \cdot 2 \pm 0 \cdot 1$ \\
& $16 \mathrm{nM}$ PMA & $2 \cdot 5 \pm 0 \cdot 3$ & $0 \cdot 1 \pm 0 \cdot 1$ \\
\hline
\end{tabular}

${ }^{a}$ The cells were harvested from culture and incubated in control medium or medium containing $16 \mathrm{nM}$ PMA for $4 \mathrm{~h}$. The culture fluids (without the cells for PGE 2 and with the cells for $\mathrm{LTC}_{4}$ ) were extracted and analyzed by radioimmunoassay as described in the Methods section.

${ }^{b}$ Values shown are averages \pm the difference between the individual values and the mean values in a single experiment. The experiment was run twice with similar results. 
increased production in the $1.2 /$ anti- $\mathrm{B}^{\mathrm{r}}$ cells. This may, however, reflect the fact that the assay lacks the sensitivity to detect small changes in absolute amounts of this metabolite.

Using $\mathrm{PGE}_{2}$ as the indicator metabolite, the kinetics of production was examined

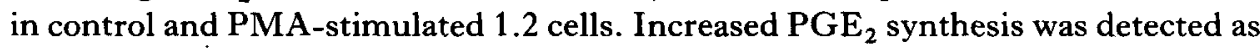
early as 5 min after stimulation with $16 \mathrm{nM}$ PMA (figure 3), suggesting that the rapid release of arachidonic acid from pre-labeled cells was accompanied by increased metabolism of the released material.

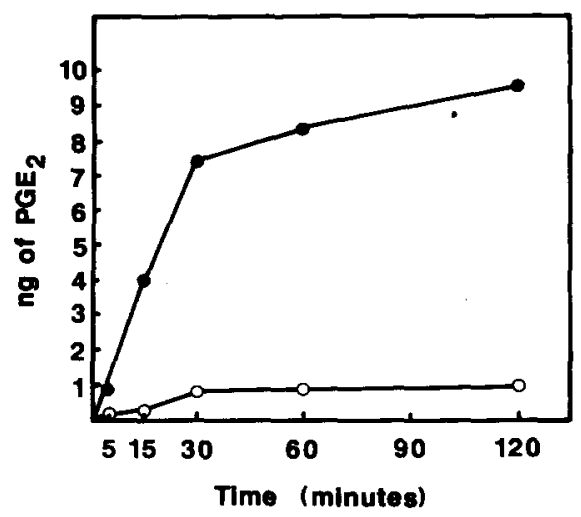

Figure 3. Time-course of $\mathrm{PGE}_{2}$ production by the 1.2 cells. The cells were harvested from culture and incubated for varying periods of time in control medium and in medium stimulated with $16 \mathrm{nM}$ PMA. At the appropriate times, the culture fluids were harvested and analyzed for $\mathrm{PGE}_{2}$ as described in the Methods section. $\mathrm{O}$, Unstimulated; 16 nM PMA.

\section{Discussion}

In the present study, we examined phorbol ester binding by two cell lines derived from a murine fibrosarcoma and phorbol ester-stimulated arachidonic acid metabolism in the same cells. These lines were examined because although they are derived from the same parent tumor, they respond very differently to stimulation with phorbol esters. The 1.2 cells are chemotactically responsive [26] and rapidly attach and spread when stimulated with these agents [26 and this report]. The $1.2 /$ anti- $\mathrm{B}^{\mathrm{r}}$ cells attach and spread much more slowly when stimulated and there is no demonstrable stimulation of motility [26 and this report]. In spite of these differences, the phorbol ester binding characteristics of the two cell lines were found in the present study to be very similar. The kinetics of ligand binding and the apparent affinity of the receptor for the ligand were almost identical for the two cell lines. Likewise, the specificity of the receptor from the two lines also appeared to be indistinguishable based on competition studies using several different phorbol esters. Based on these observations, it is reasonable to suggest that the differences in biological activity between the two cell lines are not the result of differences in the initial interaction between the ligand and the cells.

Although the two cell lines appeared to be indistinguishable in their initial interaction with the phorbol esters, there may be differences between the lines in how the signal generated by ligand binding is transduced. This may result from 
quantitative or qualitative differences related to arachidonic acid metabolism. When the highly responsive 1.2 cells were stimulated with PMA there was a rapid release of arachidonic acid from phospholipid pools and a rapid conversion into cyclooxygenase and lipoxygenase metabolites. With the $1.2 /$ anti- $\mathrm{B}^{r}$ cells, the release of arachidonic acid from prelabeled cells occurred more slowly. Perhaps more importantly, the overall amount of arachidonic acid released was much less from the 1.2/anti- $\mathrm{B}^{\mathrm{r}}$ cells and correspondingly smaller amounts of metabolites were formed. In fact, we detected no increase in $\mathrm{LTC}_{4}$ levels over baseline values in the PMAstimulated 1.2/anti-B $\mathbf{B}^{\mathrm{r}}$ cells. Metabolites of arachidonic acid, in particular, lipoxygenase products, are known to serve as internal mediators of stimulus-coupled responses in other cells [10]. It may be, therefore, that the ability of the fibrosarcoma cells to respond biologically to phorbol esters is controlled, at least in part, by the inherent capacity of the cells to metabolize arachidonic acid and produce biologically important mediators from this essential fatty acid.

The identification of PMA-sensitive and PMA-resistant variants from the same parent line is not unique to the murine fibrosarcoma cells investigated here. Previous investigations have identified proliferative and non-proliferative variants of 3T3 cells [3] and growth factor-producing and non-producing variants of the $\mathrm{EL}_{4}$ lymphoma [18]. The PMA-responsive and non-responsive variants of both cell lines bind phorbol esters with indistinguishable characteristics. With the 3T3 cells, ligand binding by both the responsive and non-responsive variants led to an equivalent stimulation of protein kinase $\mathrm{C}$ activity and comparable early phosphorylation events [2]. It was also shown, that both the proliferative and the non-proliferative variants produced arachidonic acid metabolites in response to phorbol ester stimulation [4]. This was of interest since at least one of the arachidonic acid metabolites produced, i.e. prostaglandin $F_{2 \alpha}$, is known to be a potent mitogen for the 3T3 cells [12]. Although these observations might suggest substantial differences between the $3 \mathrm{~T} 3$ cells and the murine fibrosarcoma cells under investigation here, it should be noted that the proliferative variants of the 3T3 cells produced greater quantities of arachidonic acid metabolites in both the presence and absence of stimulation than did the non-responsive variants [4]. Thus, the murine fibrosarcoma cells and the $3 \mathrm{~T} 3$ cells may be comparable. If, in fact, the capacity to metabolize arachidonic acid is necessary for subsequent biological responses to phorbol ester stimulation, then the question that needs to be addressed is how the binding of the phorbol esters leads to the kinds of changes in arachidonic acid metabolism that produce the biological response. While our studies with the murine fibrosarcoma cells are directed toward understanding those responses, i.e. adhesiveness and motility, which may contribute to the capacity for invasion and metastasis, this question is of significance in other areas of investigation as well.

\section{Acknowledgments}

This stidy was supported in part by grant CA36132 from the USPHS and by grant BC 512 from the American Cancer Society.

\section{References}

[1] Aswanikumar, S., Corcoran, B., Schiffmann, E., Day, A. R., Freer, R. J., Showell, H. J., Becker, E. L., and PerT, C. B., 1977, Demonstration of a receptor on rabbit neutrophils for chemotactic peptides. Biochemical and Biophysical Research Communications, 74, 810-817. 
[2] Bishop, R., Martinez, R., Weber, M. J., Blackshear, P. J., Beatty, S., Lim, R., and Herschman, H. R., 1985, Protein phosphorylation in a tetradecanoyl phorbol acetatenonproliferative variant of 3T3 cells. Molecular and Cellular Biology, 5, 2231-2237.

[3] Blumberg, P. M., Butler-Gralla, E., and Herschman, H. R., 1981, Analysis of phorbol ester receptors in phorbol ester unresponsiveness $3 \mathrm{~T} 3$ cell variants. Biochemical and Biophysical Research Communications, 102, 818-823.

[4] Butler-Gralla, E., Taplitz, S., and Herschman, H. R., 1983, 12-O-tetradecanoyl phorbol-13-acetate stimulates release of arachidonic acid, prostaglandin $E_{2}$ and prostaglandin $F_{2 \alpha}$ from TPA nonproliferative variants of 3T3 cells. Biochemical and Biophysical Research Communications, 111, 194-199.

[5] Chang, J., 1983, Characterization of a high-affinity receptor for phorbol esters in rat alveolar macrophages. Inflammation, 7, 15-23.

[6] Clark, P. R. H., and Varani, J., 1984, Phorbol ester binding to chemotactically responding and nonresponding Walker 256 carcinosarcoma cells. Cancer Research, 44, 4967-4971.

[7] Driedger, P. E., and Blumberg, P. M., 1980, Specific binding of phorbol ester tumor promoters. Proceedings of the National Academy of Sciences, U.S.A., 77, 567-571.

[8] Fligiel, S. E. G., Perone, P., and Varani, J., 1985, Arachidonic acid metabolism in murine fibrosarcoma cells with differing in vivo and in vitro characteristics. International Journal of Cancer, 36, 383-388.

[9] Folch, J., Lees, M., Sloane Stanley, G. N., 1957, A simple method for the isolation and purification of total lipids from animal tissues. Journal of Bialogical Chemistry, 226, 497-509.

[10] Goldman, D. W., and Goetzl, E. J., 1983, Mediation and modulation of immediate hypersensitivity and inflammation by products of the oxygenation of arachidonic acid. Handbook of Inflammation, Vol. 4, edited by P. A. Ward (Amsterdam: Elsevier), pp. 163-188.

[11] Horowitz, A. D., Greenbaum, E., and Weinstein, I. B., 1981, Identification of receptors for phorbol ester tumor promoters in intact mammalian cells and an inhibitor of receptor binding in biological fluids. Proceedings of the National Academy of Sciences, U.S.A., 78, 2315-2319.

[12] Jimenez, A., Clingan, L. D., and RudLANd, P. S., 1975, Initiation of cell proliferation in cultured mouse fibroblasts by prostaglandin $\mathrm{F}_{2 \alpha}$. Proceedings of the National Academy of Sciences, U.S.A., 72, 2724-2725.

[13] Lam, W. C., Delikatny, E. J., OrR, F. W., Wass, J., Varani, J., and Ward, P. A., 1981, The chemotactic response of tumor cells: A model for cancer metastasis. American Journal of Pathology, 104, 69-76.

[14] Marasco, W. A,, Ward, P. A., Feltner, D. E., and Varani, J., 1985, Chemotactic factor binding by metastatic tumor cells: Evidence for a formylpeptide receptor on a nonmyelogenous cell. Journal of Cell Science, 73, 121-134.

[15] Munson, P. J., and RodGaRd, D., 1980, LIGAND: A versatile computerized approach for characterization of ligand-binding systems. Analytical Biochemistry, 107, 220-239.

[16] Ozaki, T., Yoshida, K., Ushijima, K., Hayashi, H., 1971, Studies on the mechanisms of invasion in cancer. II. In vivo effects of a factor chemotactic for cancer cells. International Journal of Cancer, 7, 93-100.

[17] Rayner, D. C., ORR, F. W., and Shiu, R. P., 1985, Binding of formyl peptides to Walker 256 carcinosarcoma cells and the chemotactic response of these cells. Cancer Research, $45,2288-2293$.

[18] Sando, J. J., Hilfiker, M. L., Piacentini, M. J., and Laufer, T. M., 1982, Identification of phorbol ester receptors in T-cell growth factor-producing and nonproducing EL4 mouse thymoma cells. Cancer Research, 42, 1676-1682.

[19] Sando, J. J., Hilfiker, M. L., Salomon, D. S., and Farror, J. J., 1981, Specific receptors for phorbol esters in lymphoid cell populations: Role in enhanced production of T-cell growth factor. Proceedings of the National Academy of Sciences, U.S.A., 78, 1189-1193.

[20] Scatchard, G., 1949, The attraction of proteins for small molecules and ions. Annals of the New York Academy of Sciences, 51, 660-672.

[21] Shoyad, M., and Todaro, G. J., 1980, Specific, high-affinity cell membrane receptors for biologically-active phorbol and ingenol esters. Nature, 288, 451-455. 
[22] Skipski, V. P., Peterson, R. F., and Barclay, M., 1964, Quantitative analysis of phospholipids by thin layer chromatography. Biochemical Journal, 90, 374-378.

[23] Varani, J., 1982, Chemotaxis of metastatic tumor cells. Cancer Metastasis Reviews, 1, $17-28$.

[24] Varani, J., Wass, J., Piontek, G., and Ward, P. A., 1981, Chemotactic factor-induced adherence of tumor cells. Cell Biology International Reports, 5, 525-530.

[25] Varani, J., and FAntone, J. C., 1982, Phorbol myristate acetate-induced adherence of Walker 256 carcinosarcoma cells. Cancer Research, 42, 190-197.

[26] Varani, J., Fligiel, S. E. G., and Perone, P., 1985, Directional motility in strongly malignant murine tumor cells. International Journal of Cancer, 35, 559-564.

[27] Varani, J., Lovett, E. J., Wicha, M., Malinoff, H., and McCoy, J. P., 1983, Cell surface $\alpha$-D-galactopyranosyl end groups: use as a marker in the isolation of murine tumor cell lines with varying malignant potential. Journal of the National Cancer Institute, 71, 1281-1286.

[28] Williams, L. T., Snyderman, R., Pike, M. C., and Lefkowitz, R. J., 1977, Specific receptor sites for chemotactic peptides on human polymorphonuclear leukocytes. Proceedings of the National Academy of Sciences, U.S.A., 74, 1204-1208. 